\title{
Genetic diversity of local corn (Zea mays) cultivars from South Amarasi, Kupang District, Indonesia by Inter Simple Sequence Repeats marker
}

\author{
USLAN", NUR JANNAH \\ Department of Biology Education, Faculty of Teacher Training and Education, Universitas Muhammadiyah Kupang. Jl. KH. Ahmad Dahlan No. 17, \\ Kayu Putih, Oebobo, Kupang City 85111, East Nusa Tenggara, Indonesia. Tel.: +62-813-39430274, `email: uslanspd@ gmail.com
}

Manuscript received: 19 December 2019. Revision accepted: 24 February 2020.

\begin{abstract}
Uslan, Jannah N. 2020. Genetic diversity of local corn (Zea mays) cultivars from South Amarasi, Kupang District, Indonesia by Inter Simple Sequence Repeats marker. Biodiversitas 21: 1208-1214. Corn (Zea mays L.) is one of the most important food crops in Indonesia. However, the studies described their genetic variation is relatively poor. Therefore, the aim of this study was to analyze the genetic diversity of local corn cultivars from South Amarasi, Kupang District, East Nusa Tenggara (NTT), Indonesia using ISSR markers. The sampling was conducted in 4 different sites in Sub-district of Amarasi, Kupang District. A total of 11 corn cultivars from Sub-district of South Amarasi was collected. DNA isolation was performed by using CTAB Method. Clustering analysis was conducted on MSVP 3.2 software. It was shown that all ISSR-primers used (UBC 811, UBC 814 and UBC 824) were successfully produced polymorphic bands and represents the high genetic diversity of the local corn cultivars. The genetic distance index indicated that several corn cultivars from two different populations were geographically unclustered, although there are samples from several populations that have a low genetic distance. The genetic variation index also showed high genetic diversity among the populations. Further research on the exhaustive sample collection was needed to give an insight into the genetic diversity of local corn cultivars (Zea mays L.) from South Amarasi, Indonesia. Please write implementation of this research
\end{abstract}

Keywords: ISSR, genetic diversity, East Nusa Tenggara, Zea mays

\section{INTRODUCTION}

Zea mays (corn) is one of the most important food crops in the world especially in Indonesia (Djaini et al. 2014). The demand for corn is used by producers as a substitute for rice which processed into various forms (Yusuf et al. 2013). The high demand for corn was making several areas in Indonesia as the largest producer of corn including East Java, Central Java, Lampung, South Sulawesi, North Sumatra, and East Nusa Tenggara (NTT) (BPS 2018).

Kupang District with an area of 26.138 ha, is capable of producing 64.979 tons of corn, making Kupang the highest producer of corn in East Nusa Tenggara (NTT) after Timor Tengah Selatan and Belu Sub-districts (BPS 2009). Subdistrict of South Amarasi, Kupang District, East Nusa Tenggara Province is an area whose food plants are dominated by corn. Ironically, corn productivity in this region was considered low (2.48 tons/ha in 2014), lower than the national corn productivity (BPS 2015). This case is due to the local farmers that prefer to use local cultivars rather than hybrid corn (Faesal and Syuryawati 2011). Specifically, corn plants in the province of East Nusa Tenggara are dominated by local corn cultivars (37\%) and the remainders are varieties of Jagung Bersari (16\% of lamuru varieties) and hybrid corn (6\%) (Subagio and Aqil 2013; Murningsih et al. 2015). In this case, breeding efforts are needed to increase corn production through plant breeding by knowing the information of its genetic diversity. Information on genetic variation, genetic distance, and genetic relationship of corn from each population, can be used as references in further breeding programs in producing corn with high-yielding varieties in the South Amarasi Sub-district (Reni 2015).

Variation or genetic diversity of plants can be assessed by morphological and molecular approaches (Beyene et al. 2005; Iqbal et al. 2015; Sundari et al. 2019). However, the use of morphological characters is considered weak to infer the genetic diversity, due to the similarity of characters, subjectivity of examiners, and similar characters as a result of convergent evolution (Sundari et al. 2017; Gusmiati et al 2018; Probojati et al. 2019). Therefore, the use of molecular markers is one of the reliable approaches that often used to determine the genetic diversity of corn. Molecular approaches that regularly used to assess genetic variation or diversity include Random Amplification of Polymorphic DNA (RAPD) (Lopes et al. 2017; Probojati et al. 2019), Restriction Fragment Length Polymorphism (RFLP) (Darrah et al. 2019), Simple Sequence Repeat (SSR) (Guevarra et al. 2017), and Inter Simple Sequence Repeat (ISSR) (Dar et al. 2018). ISSR is considered a reliable method that has a high reproducibility rate with a primers length of up to 16-25 mers (Costa et al. 2016). Previously, researchers have assessed the genetic diversity of some local corn cultivars in the Kupang District which is Amarasi, Fatule'u and Nekameses Sub-districts based on ISSR with a fairly high level of genetic diversity (approximately $0.30-0.80$ similarity values) (Yulita and Naiola 2013). However, the genetic diversity research on 
the local corn cultivars in other sub-Sub-districts is needed, especially in South Amarasi Sub-district. Therefore, the aim of this study was to analyze the genetic diversity of local corn cultivars from South Amarasi Sub-district, Kupang District, East Nusa Tenggara (NTT), Indonesia using ISSR markers.

\section{MATERIALS AND METHODS}

\section{Sample collection}

Young leaves of local corn (Zea mays L.) cultivars were collected from a total of 4 sampling sites location from South Amarasi Sub-district, Kupang District, East Nusa Tenggara (NTT), Indonesia; and analyzed at Animal Physiology Laboratory of Department of Biology, Brawijaya University, Malang and Biology Laboratory of FKIP Muhammadiyah University of Kupang. Three of local corn cultivars in every population were collected their leaves for DNA extraction. A total of 11 corn cultivars from South Amarasi Sub-district was collected including, Sahraen Village, Retraen Village, Nekmese Village, and Buraen Village. The chosen sites were marked its coordinates and altitude as shown in Table 1.

\section{DNA isolation and DNA quantification}

A total of $0.1 \mathrm{~g}$ of samples were ground to powder using mortar and pestle. DNA isolation was carried out using the CTAB method, developed by Doyle and Doyle (Doyle and Doyle 1990), with modification by Pharmawati (2009). The powdered sample was added by $1 \mathrm{~mL}$ extraction buffer $[2 \%$ CTAB, $1,4 \mathrm{M} \mathrm{NaCl}, 0.2 \% \quad \beta$ mercaptoethanol, $50 \mathrm{mM} \mathrm{Na}{ }_{2}$ EDTA $(\mathrm{pH} \mathrm{8,0)}$ and $100 \mathrm{mM}$ Tris-HCL $\quad(\mathrm{pH} \quad 8,0)]$ that contained $0.2 \% \quad \beta$ mercaptoethanol. The samples were incubated at $65^{\circ} \mathrm{C}$ using a water bath for 60 minutes and turned frequently for every 10 minutes. A total of $700 \mu \mathrm{l}$ chloroform: isoamyl alcohol (24:1) was added into suspension and homogenized using Vortex. Suspension was centrifuged at $12.000 \mathrm{rpm}$ at room temperature for 5 minutes. The supernatant was transferred into a new tube, with the addition of cold ethanol, adjusting to a total volume of supernatant. The suspension was mixed gently and incubated for 1 hour at$20^{\circ} \mathrm{C}$ temperature. The incubated suspension was centrifuged at $12.000 \mathrm{rpm}$ for 3 minutes, and the pellets were washed by $400 \mu \mathrm{l}$ of $70 \%$ alcohol. Pellets were dried out, then added with $100 \mu \mathrm{l}$ of sterilized ddH2O to dissolve the DNA pellets. The tubes were transferred to- $20^{\circ} \mathrm{C}$ temperature storage (Uslan and Pharmawati 2015).

The quality of isolated DNA was evaluated by a qualitative test. The qualitative test was carried out by electrophoresis on 1,8\% agarose gel with $1 \mathrm{x}$ TAE buffer [40 mM Tris-acetate ( $\mathrm{pH} 7.9)$ and $2 \mathrm{mM}$ Na2EDTA]. A total of $0.5 \mathrm{~g}$ agarose was added to $50 \mathrm{ml}$ TAE buffer, then transferred into Erlenmeyer tubes and incubated for 2 minutes in a microwave. Agarose gels were placed into electrophoresis chambers and submerged on $1 \mathrm{x}$ buffer TAE. A total of $3 \mu \mathrm{L}$ of samples were mixed with loading dye on parafilm paper. Lambda DNA (50ng/ $\mu$ l) with a concentration of $2 \mu \mathrm{l}, 4 \mu \mathrm{l}, 6 \mu \mathrm{l}$ was inserted into the well to estimate the DNA concentration. Electrophoresis was carried out at a voltage of 100 volts for 30 minutes, then stained by submerging the gels on Ethidium bromide $(\mathrm{EtBr})$ for 30 minutes. The agarose gels were visualized using Gel DOC, UV-Transilluminator (Bio-Rad) (Sambrook and Russel 2001).

\section{ISSR-PCR}

ISSR-PCR analysis was performed using 3 primers (Table 2) with PCR Thermocycler Bio-Rad. The selection of primers based on previous study by Muhammad et al. (2017) and Dar et al. (2018). Total volume of PCR reaction mix was $20 \mu \mathrm{l}$ consisting of $12 \mu \mathrm{l}$ master mix (consisted of $2 \mu \mathrm{l}$ dNTP mix [dATP, dTTP, dGTP, and dCTP]; $2 \mu \mathrm{l} \mathrm{Taq}$ buffer polymerase; $1.5 \mu \mathrm{l} \mathrm{MgCl} 2 ; 0.2 \mu \mathrm{l}$ Taq polymerase; 1 $\mu \mathrm{l}$ glycerol; $2.3 \mathrm{ddH} 2 \mathrm{O}$ ), $8 \mu \mathrm{l}$ of UBC primer, and $3 \mu \mathrm{l}$ DNA template. ISSR-PCR was performed by DNA predenaturation at $94^{\circ} \mathrm{C}$ for $5 \mathrm{~min}$ for 1 cycles, followed by 45 cycles of denaturation at $94^{\circ} \mathrm{C}$ for $1 \mathrm{~min}$, annealing at $40^{\circ} \mathrm{C}$ for $90 \mathrm{sec}$, extension at $72^{\circ} \mathrm{C}$ for $2 \mathrm{~min}$. The final extension was performed at $72^{\circ} \mathrm{C}$ for 7 minutes for 1 cycle. ISSR fragments were separated by electrophoresis method on 1.8 agarose gels in 1xTAE buffer for 40 minutes at 100 volts for 40 minutes, then submerged in Ethidium bromide (EtBr) for $30 \mathrm{~min}$. Then, the ISSR profiles on the gels were visualized by gel DOC, UV-Transilluminator (Bio-Rad) with a $100 \mathrm{bp}$ of DNA ladder marker to determine the size of DNA amplification products (Sambrook and Russel 2001).

Table 1. Sampling Sites location of local corn cultivars (Zea mays L.) from South Amarasi Sub-district, Kupang District, Indonesia with notes on location coordinate and altitude

\begin{tabular}{|c|c|c|c|}
\hline $\begin{array}{c}\text { Sampling } \\
\text { sites } \\
\text { (village) } \\
\end{array}$ & $\begin{array}{c}\text { Total } \\
\text { samples }\end{array}$ & Location coordinate & $\begin{array}{r}\text { Altitude } \\
\text { (m asl.) }\end{array}$ \\
\hline \multirow[t]{3}{*}{ Sahraen } & \multirow{3}{*}{3} & $123^{\circ} 70.7396^{\prime} \mathrm{E} 10^{\circ} 22.9108^{\prime} \mathrm{s}$ & 387. \\
\hline & & $123^{\circ} 83.847^{\prime} \mathrm{E} 10^{\circ} 15.5283^{\prime} \mathrm{S}$ & 356 \\
\hline & & $123^{\circ} 83.6104^{\prime} \mathrm{E} 10^{\circ} 15.3526^{\prime} \mathrm{S}$ & 400 \\
\hline \multirow{3}{*}{ Retraen } & \multirow{3}{*}{3} & $123^{\circ} 83.3739^{\prime} \mathrm{E} 10^{\circ} 15.1769^{\prime} \mathrm{S}$ & 180 \\
\hline & & $123^{\circ} 82.3639^{\prime} \mathrm{E} 10^{\circ} 53.03^{\prime} \mathrm{S}$ & 168 \\
\hline & & $123^{\circ} 82.3137^{\prime} \mathrm{E} 10^{\circ} 85.91^{\prime} \mathrm{S}$ & 174 \\
\hline \multirow[t]{2}{*}{ Buraen } & \multirow{2}{*}{3} & $123^{\circ} 81.9457^{\prime} \mathrm{E} 10^{\circ} 12.8541^{\prime} \mathrm{S}$ & 300 \\
\hline & & $123^{\circ} 82.8303^{\prime} \mathrm{E} 10^{\circ} 13.6701 ’ \mathrm{~S}$ & 274 \\
\hline \multirow{3}{*}{ Nekmese } & \multirow{3}{*}{3} & $123^{\circ} 82.5679^{\prime} \mathrm{E} 10^{\circ} 18.251^{\prime} \mathrm{S}$ & 476 \\
\hline & & $123^{\circ} 82.5731^{\prime} \mathrm{E} 10^{\circ} 19.1596^{\prime} \mathrm{S}$ & 487 \\
\hline & & $123^{\circ} 82.5683^{\prime} \mathrm{E} 10^{\circ} 186489^{\prime} \mathrm{S}$ & 500 \\
\hline
\end{tabular}

Table 2. ISSR primer used in this study

Primer $\quad$ Base sequence $\left(5^{\prime} \rightarrow 3^{\prime}\right.$ ')

$\begin{array}{ll}\text { UBC } 811 & \text { GAG AGA GAG AGA GAG AC } \\ \text { UBC } 814 & \text { CTC TCT CTC TCT CTC TA } \\ \text { UBC } 824 & \text { TCT CTC TCT CTC TCT CG }\end{array}$




\section{Data and scoring analysis}

The DNA band size was determined by plotting on semi-log paper. The bands that appear are assumed to be the ISSR allele. The migration distance from the well of visualized gels was measured to the middle of the $100 \mathrm{bp}$ ladder band and scored using PyElph vers.4.1. The X-axis was the distance from the well to mid ladder band, while Y-axis was DNA size on the ladder. The points on semi-log paper were linked to produce the standard curve (Pharmawati et al. 2005). The DNA pattern obtained was scored as present (1) and absent (0). The scored were analyzed by clustering using the UPGMA method based on Nei and Li's similarity coefficient on MSVP 3.2 software. To estimate the primers' informativeness, the calculation of Polymorphic Information Content (PIC) was carried out (Laurentin and Karlysky 2007). PIC value for each primer was calculated by using Equation 1:

$$
P I C i+2 f i(1-f i)
$$

Where, PICi: polymorphism information content of the primer i, Fi: frequency of primer fragment that was present, (1-f_i): frequency of primer fragment that was absent. The genetic variation parameters were showed by the effective alleles (na), that was calculated by using Equation 2:

$$
n a: \frac{1}{\sum_{i} p i^{2}}
$$

and a total of observed alleles (ne) was calculated by using Equation 3:

$$
\text { ne: } \frac{\text { Ealel }}{\sum \text { lokus }}
$$

and the mean of heterozygosity/ genetic variation $(\mathrm{He})$ was calculated by using Equation 4:

$$
H_{e^{*}}: 1-\Sigma_{i} p i^{2}
$$

Where, Pi is frequency if the genetic type of the i. The criterion of genetic diversity level refers to Nei (Nei 1987) where the value of genetic diversity ranges from 0.1 to 0.4 is categorized as low, while the value of $0.5-0.7$ is categorized as moderate, and value of $0.8-1.0$ is categorized as high.

\section{RESULTS AND DISCUSSION}

\section{ISSR profiles of local corn (Zea mays L.) cultivars}

The results of DNA bands pattern from 12 accession of local corn (Zea mays L.) cultivars using 3 ISSR primers indicated the various amplification size range. The amplification products ranged up from 200 to $1200 \mathrm{bp}$, however, the smear DNA appeared on several samples with one sample from Berkaen villages that cannot appear (only 11 samples were presented as shown in Figure 1). The result of DNA amplification of 11 samples of local corn cultivars (Zea mays L.) from South Amarasi Sub-district, Kupang District showed that all primers used were produced polymorphic DNA bands successfully (Figure 1). The absent and present of bands on each primer is a result of the successful attachment of primers to its homolog DNA template on a single locus (Tingey et al 1994). The technical difficulties and errors may contribute to the amplification of the DNA, resulting in the inability of primers to amplified the DNA fragment (samples from Bekaen villages). According to Uslan and Pharmawati (2015), the damaged DNA occurred as a result of released secondary metabolites when the cell was destructed by physical procedure, leading to degraded DNA shows by DNA bands that not merely be at the same intensity (shown as thick and thin DNA bands). Consequently, an evaluation of the technical procedures is needed to get an appropriate result.

The strength of ISSR primers that can amplify the DNA fragments was considered adequate. Therefore, these results exhibit that 3 ISSR primers used (Table 2) are suitable for similar studies on genetic variation of local corn cultivars (Zea mays L.). According to Weising et al. (2005) and Probojati et al (2019), the polymorphism is results of nucleotide base change that transform the primer binding site, and also an insertion or deletion within the amplified region. The polymorphism showed the number of genetic variations that exist among the samples. The high polymorphism appearance on amplification products showed high genetic diversity (Uslan and Pharmawati 2015). Accordingly, this research provides proof that indicates the high genetic diversity of local corn cultivars (Zea mays L.) from South Amarasi Sub-district, Kupang District.

\section{Polymorphism analysis of local corn (Zea mays L.) cultivars}

The total of 115 bands ranged from 200 to 1200 base pairs produced by 3 ISSR primers. The highest Numbers of Polymorphic Bands (NPB) was produced by UBC 824 (45 bands), giving the average of Polymorphic Bands (PB) to $100 \%$ (Table 3). Polymorphic Information Content (PIC) values are 0.91 on each primer. PIC as an index that indicated the most capable primers to detect the polymorphism bands, emphasize that all of these 3 ISSR primers are able to amplify the 11 samples of local corn cultivars (Zea mays L.) from South Amarasi Sub-district, Kupang District. The higher the PIC values, the more likely the primer to be used for detecting genetic diversity in a population (Roldan-Ruiz et al 2000).

Table 3. Polymorphism analysis results of 3 ISSR primers amplification of local corn cultivars (Zea mays L.) from South Amarasi Sub-district, Kupang District.

\begin{tabular}{llllll}
\hline Primer & $\begin{array}{c}\text { DNA } \\
\text { amplification } \\
\text { size (bp) }\end{array}$ & TNB & NPB & $\begin{array}{c}\text { PB } \\
(\%)\end{array}$ & PIC \\
\hline UBC 811 & $300-1100$ & 34 & 34 & 100 & 0.91 \\
UBC 814 & $200-1100$ & 36 & 36 & 100 & 0.91 \\
UBC 824 & $300-1200$ & 45 & 45 & 100 & 0.91 \\
Total & & 115 & 115 & 100 & \\
\hline
\end{tabular}

Note: TNB: total number of bands; NPB: number of polymorphic bands; PB (\%): polymorphic band percentage; PIC: polymorphism information content. 

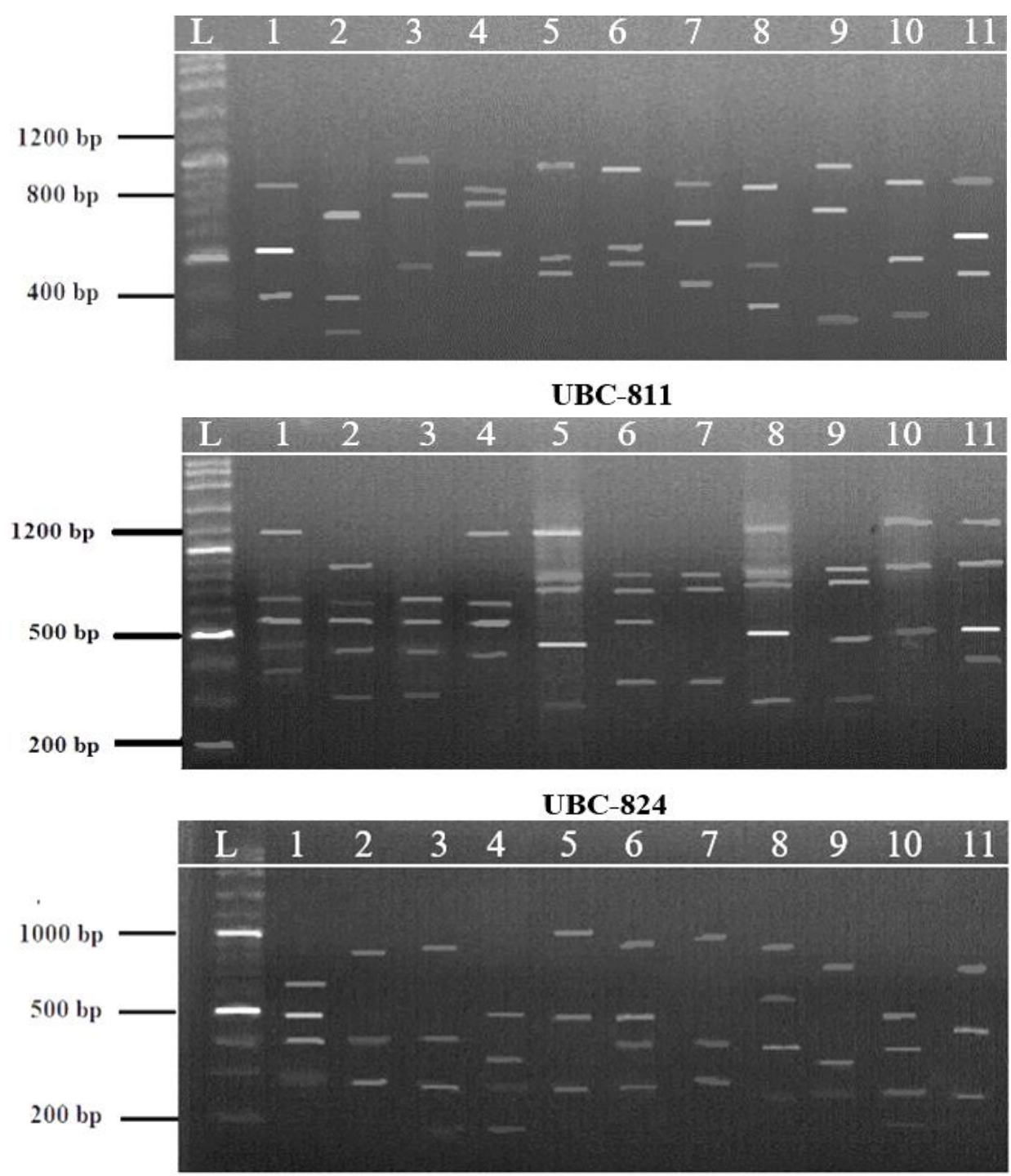

UBC-814

Figure 1 Electropherogram PCR-ISSR of local corn (Zea mays L.) cultivars from South Amarasi Sub-district, Kupang District which produced DNA polymorphic bands by several primers to with UBC-811, UBC-814, and UBC-824. (Note: Number of local corn cultivars numbers respectively, Sahraen village [1-3], Retraen village [4-6], Nekmese village [7-9] and Buraen village [10-11], DNA Ladder $100 \mathrm{bp}$ indicated by a notation of $\mathrm{L}$ )

\section{Genetic distance, clustering, and genetic variation of local corn cultivars}

Based on scoring function to elucidate genetic distance of 11 samples of local corn cultivars (Zea mays L.) from South Amarasi Sub-district, Kupang District (Table 4), indicated that similarity index with the highest genetic distance showed by local corn cultivars (Zea mays L.) from Buraen 2 and Retraen 3 populations (similarity index $0.0004)$, while the lowest genetic distance indicated by local corn cultivars (Zea mays L.) from Sahraen 3 and Sahraen 2 populations (similarity index 0.700 ). The high genetic distance showed by Buraen 2 and Retraen 3 populations indicated that these 2 samples were geographically unclustered, while the low genetic distance shows that samples from Sahraen 3 and Sahraen 2 populations from the identical locations have high similarity. The unclustering samples may be caused by the acquisition of seeds from a local farmer to other farmers to a different area. Also, differences in the genetic distance may occur due to insect-assisted pollination. According to Uslan and Pharmawati (2015), the process of outcrossing that assisted by wind or insects leads to greater opportunities to distribute to wider areas. 
Table 4. Similarity matrix of clustering by UPGMA methods using Nei and Li's coefficients of 11 local corn (Zea mays L.) cultivars from South Amarasi Sub-district, Kupang District, the lowest and highest similarity values was indicated by red colors.

\begin{tabular}{|c|c|c|c|c|c|c|c|c|c|c|c|c|}
\hline & & 1 & 2 & 3 & 4 & 5 & 6 & 7 & 8 & 9 & 10 & 11 \\
\hline 1 & Sahraen 1 (1) & 1.000 & & & & & & & & & & \\
\hline 2 & Sahraen 2 (2) & 0.364 & 1.000 & & & & & & & & & \\
\hline 3 & Sahraen 3 (3) & 0.273 & 0.700 & 1.000 & & & & & & & & \\
\hline 4 & Retraen 1 (4) & 0.435 & 0.286 & 0.286 & 1.000 & & & & & & & \\
\hline 5 & Retraen 2 & 0.261 & 0.190 & 0.286 & 0.273 & 1.000 & & & & & & \\
\hline 6 & Retraen 3 & 0.261 & 0.286 & 0.381 & 0.273 & 0.545 & 1.000 & & & & & \\
\hline 7 & Nekmese 1 & 0.182 & 0.300 & 0.300 & 0.190 & 0.476 & 0.476 & 1.000 & & & & \\
\hline 8 & Nekmese 2 & 0.174 & 0.190 & 0.286 & 0.182 & 0.455 & 0.455 & 0.381 & 1.000 & & & \\
\hline 9 & Nekmese 3 & 0.095 & 0,005 & 0.105 & 0.200 & 0.500 & 0.400 & 0.316 & 0.300 & 1.000 & & \\
\hline 10 & Buraen 1 & 0.182 & 0.100 & 0.100 & 0.286 & 0.190 & 0.286 & 0.200 & 0.381 & 0.211 & 1.000 & \\
\hline 11 & Buraen 2 & 0.091 & 0.200 & 0.100 & 0.286 & 0.095 & 0.004 & 0.100 & 0.095 & 0.105 & 0.400 & 1.000 \\
\hline
\end{tabular}

Table 5. Result of genetic variation estimation of local corn (Zea mays L.) cultivars from 4 different populations of South Amarasi, Kupang District.

\begin{tabular}{lcllc}
\hline Population & $\begin{array}{c}\text { Total } \\
\text { samples }\end{array}$ & Na & Ne & He \\
\hline Sahraen & 3 & 2.977 & 10.667 & 0.664 \\
Retraen & 3 & 3.000 & 11.000 & 0.667 \\
Buraen & 2 & 2.980 & 10.000 & 0.664 \\
Nekmese & 3 & 2.000 & 6.667 & 0.500 \\
Total & 11 & 10.957 & 38.333 & 2.495 \\
Mean & & 2.739 & 9.583 & 0.624 \\
\hline
\end{tabular}

Note: Na: total alleles observed; Ne: total effective alleles; He: genetic variation

Dendrogram depicting the clustering of all samples (Figure 2), showed that from 11 samples of local corn (Zea mays L.) cultivars from South Amarasi Sub-district, Kupang District is divided to 3 main clusters and 9 subclusters (based on similarity coefficient $0.50 / 50 \%$ ). Cluster I consists of Buraen 2 (sub-cluster 1), Buraen 1 (sub-cluster 2). Cluster II consists of Nekmese 3 (subcluster 3), Nekmese 2 (sub-cluster 4), Nekmese 1 (subcluster 5), Retraen 3 and Retraen 2 (sub-cluster 6). Cluster III consists of Sahraen 3 and Sahraen 2 (sub-cluster 7), Retraen 1 (sub-cluster 8), Sahraen 1 (sub-cluster 9). According to Wijayanto et al. (2013), the smaller the coefficient of similarity (toward 0 values), the farther the relationship, vice versa. Some populations showed a close genetic relationship, although the remainders do not form close relationships, even though, they are originated from the identical population. This shows that some relationships between the samples do not influence by geographical factors. According to Poerba and Martanti (Poerba and Martanti 2008), this case is due to the influence of genetic recombination. According to Karuniawan et al. (2008), samples from the identical population do not invariably have a close relationship, which may be influenced by genotypic interactions with the environment. ISSR as universal primers, randomly amplifies genomes (Kusumadewi et al. 2010) and becomes more complex in the case of outcrossing Rimbawanto et al. 2006).

The result was shown that the genetic variation index (He) from South Amarasi Sub-district, Kupang District ranging from 0.500 to 0.667 , indicating the high genetic diversity. the average number of total alleles observed $(\mathrm{Na})$ was 2.739 and the average number of total effective alleles $(\mathrm{Ne})$ was 9.583 . The average number of genetic variation (He) shows a value of 0.624 . Based on the results of the analysis, the population of local corn cultivars from the Retraen population showed the highest genetic variation (He) 0.667, while the Buraen population showed the lowest genetic variations (Table 5). High variations value can be caused by the influence of environmental conditions. Soil and climate conditions in Kupang areas are considered as dry and arid, in addition to topography and environmental stress, create such a limiting factor in local corn cultivars selections for long periods. This selection process produces plants that genetically have higher environmental stress capabilities. Many factors were known to influence the degree of variations. According to Ardiyani et al. (2014), high differentiation among the population as well as low genetic diversity in a population is a result of dominating the self-pollination system compared to cross-pollination or outcrossing.

Genetic diversity that points out the amount of genetic variation is valuable information to support the conservation and breeding efforts (Ihwan et al. 2019). The process that causes whether low or high genetic variations were considered fundamental, given the genetics as the basic element in hierarchical biology (Zulfahmi 2013). As basic information, genetic variation can be used as a basis for conservation efforts, breeding programs, and sustainable use of genetic resources (Ardiansyah et al. 2018). 

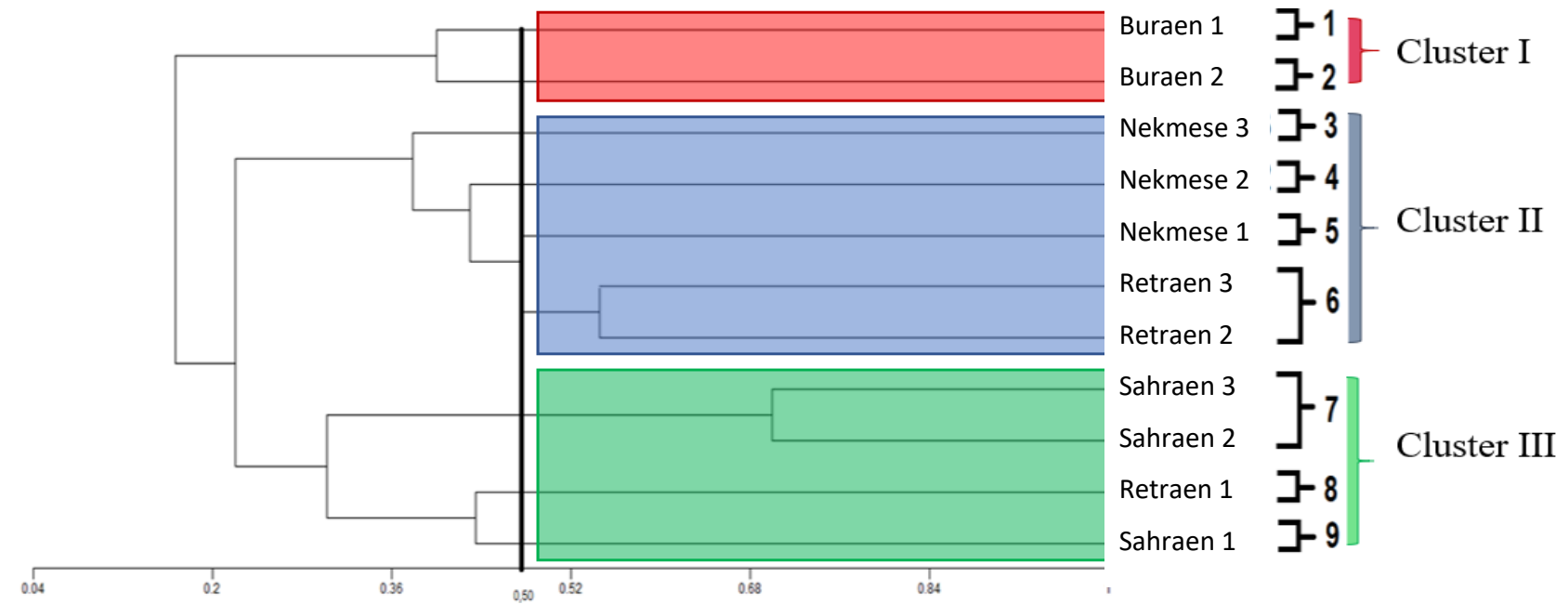

Figure 2. Dendrogram of 11 samples of local corn (Zea mays L.) cultivars from South Amarasi Sub-Sub-district, Kupang District based on Nei and Li's coefficient

ISSR-PCR analysis of 11 samples of local corn cultivars (Zea mays L.) from South Amarasi Sub-district, Kupang District, showed that all ISSR-primers used (UBC 811, UBC 814 and UBC 824) were suitable and successfully produced polymorphic DNA bands pattern, represents the high genetic diversity of the samples. The genetic distance showed by the similarity index indicated that several samples from two different populations were geographically indifferent, although there are samples from several populations that have a low genetic distance. The dendrogram divided the samples into 3 main clusters, although some populations showed a close genetic relationship and the remainders were not, indicating the absence of geographical influence. The genetic variation index also showed high genetic diversity among the populations. Further research on the exhaustive sample collection was needed to give an insight into the genetic diversity of local corn (Zea mays L.) cultivars from South Amarasi Sub-district, Kupang District, East Nusa Tenggara (NTT) Province, Indonesia.

\section{ACKNOWLEDGEMENTS}

We greatly appreciate for chief and assistant laboratory of Animal Physiology Laboratory of Department of Biology, Brawijaya University, Malang, Indonesia who have given us permission to complete this research in their laboratory. The author also would thank Abdul Hakim, Ahmad Yani, Abka Abdullah, Vinsensius Kopong Sabon as a team of this research.

\section{REFERENCES}

Ardiyani M, Sulistyaningsih LD, Esthi YN. 2014. Keragaman genetik Tacca leontopetaloides (L.) Kuntze (Taccaceae) dari beberapa provenansi di Indonesia berdasarkan Marka Inter Simple Sequence Repeats (ISSR). Berita Biologi 13 (1): 85-96. [Indonesian]
Adriansyah F, Hanum L, Muharni M, Windusari Y. 2018. Analisis polimorfisme padi varietas lokal Sumatera Selatan berdasarkan pendekatan PCR-RAPD. Jurnal Lahan Suboptimal 7 (1): 50-58. [Indonesian]

Beyene Y, Botha AM, Myburg AA. 2005. Genetic diversity in traditional Ethiopian highland maize accessions assessed by AFLP markers and morphological traits. Afr J Biotechnol 4 (7): 586-595.

BPS. 2009. East Nusa Tenggara Dalam Angka 2009. https://www.bps.go.id/

BPS. 2015. East Nusa Tenggara Dalam Angka 2015 https://www.bps.go.id/

BPS. 2018. Produksi Jagung Menurut Kabupaten/Kota d. Badan Pusat Statistik, Jakarta, Indonesia.

Costa R, Pereira G, Garrido I, Tavares-de-Sousa MM, Espinosa F. 2016 Comparison of RAPD, ISSR, and AFLP molecular markers to reveal and classify orchardgrass (Dactylis glomerata L.) Germplasm Variations. PloS one 11 (4): e0152972

Dar TH, Shakeel R, Verma S. 2018. Comparative Germplasm Characterization of Maize (Zea mays L.) in Rajouri Region of Pir Panjal Himalaya J \& K (India), based on Morphological and ISSR Markers. J Crop Sci Biotech. DOI: 10.1007/s12892-017-0128-0

Darrah LL, McMullen MD, Zuber MS. 2019. Breeding, Genetics and Seed Corn Production. Woodhead Publishing, Cambridge.

Djaini V 2014 Respon pertumbuhan tanaman jagung lokal (Zea mays L.) varietas Motoro Kiki berdasarkan waktu pemberian pupuk kotoran ayam [Master thesis]. Jurusan Agroteknologi Fakultas Pertanian Universitas Gorontalo, Gorontalo. [Indonesian]

Dar TH, Shakeel R, Verma S. 2018. Comparative germplasm characterization of maize (Zea mays L.) in Rajouri Region of Pir Panjal Himalaya J \& K (India), based on morphological and ISSR markers. J Crop Sci Biotechnol 21 (1): 43-55.

Doyle JJ, Doyle JL. 1990. Isolation of plant DNA from fresh tissue. Focus 12 (13): 39-40.

Faesal, Syuryawati S. 2011. Urgensi koleksi plasma nutfah jagung lokal di Flores East Nusa Tenggara. Seminar Nasional Serelia. Balai Penelitian Tanaman Serealia, Maros. [Indonesian]

Guevarra PR, Diaz DC, Canama AO. 2017. Molecular characterization of native corn populations in the Philippines based on SSR markers. Philipp J Crop Sci 42: 111-121.

Gusmiati LH, Hapsari L, Wahyudi D. 2018. Keragaman dan pengelompokan morfologi 10 pisang olahan (Musa cv. Grup ABB) koleksi Kebun Raya Purwodadi LIPI. Floribunda 5 (8): 299-313. [Indonesian]

Ihwan, Uslan, Widodo, Hakim L 2019 Genetic diversity of Rhizophora mucronata in eastern region of Timor Island, Indonesia as revealed by RAPD. Biodiversitas 20 (11): 3364-3371.

Iqbal J, Shinwari ZK, Rabbani MA. 2015. Prediction of grain yield losses in wheat (Triticum aestivum L.) under different densities of wild oat (Avena fatua L.). Pak J Bot 47: 255-264. 
Karuniawan A, Sahala B, Ismail A. 2008. Keanekaragaman genetik mucuna berdasarkan karakter morfologi dan komponen hasil. Zuriat 19 (1): 41-59. [Indonesian]

Kusumadewi Y, Poerba YS, Partomihardjo T. 2010. Keragaman genetika ramin [Gonystylus bancanus (Miq.) Kurz] dari Provinsi Riau berdasarkan profil Random Amplified Polymorphic DNA. Jurnal Biologi Indonesia 6 (2): 173-183. [Indonesian]

Laurentin H, Karlovsky P. 2007. AFLP fingerprinting of sesame (Sesamum indicum L.) cultivars: Identification, genetic relationship and comparison of AFLP informativeness parameters. Gen Resour Crop Evol 54 (7): 1437-1446.

Lopes HM, Bastos CS, Boiteux LS, Foresti J, Suinaga FA. 2017. A RAPD-PCR-based genetic diversity analysis of Helicoverpa armigera and H. zea populations in Brazil. Genet Mol Res 16: 3-9

Muhammad RW, Qayyum A, Ahmad MQ, Hamza A, Yousaf M, Ahmad B, Younas M, Malik W, Liaqat S, Noor E. 2017. Characterization of maize genotypes for genetic diversity on the basis of inter simple sequence repeats. Genet Mol Res. DOI: 10.4238/gmr16019438.

Murningsih T, Yulita KS Bora CY, Arsal BA 2015 Respon tanaman jagung varietas lokal NTT umur sangat genjah (pena tunu'ana') terhadap cekaman kekeringan. Berita Biologi 4 (1): 49-55. [Indonesian]

Nei M. 1987. Molecular Evolutionary Genetics. Columbia University Press, New York.

Pharmawati M, Yan G, McFarlane IJ. 2005. Molecular variation and fingerprinting of Leucadendron cultivars (Proteaceae) by ISSR Markers. Aust Syst Bot 17 (1): 49-61.

Pharmawati M. 2009. Optimalisasi ekstraksi DNA dan PCR-RAPD pada Grevillea spp. (Proteaceae). Jurnal Biologi XIII 1: 12-16. [Indonesian]

Poerba YS, Martanti D. 2008. Keragaman genetik berdasarkan marka Random Amplified Polymorphic DNA pada Amorphophallus muelleri Blume di Jawa. Biodiversitas 9 (4): 245-249. [Indonesian]

Probojati RT, Wahyudi D, Hapsari L. 2019. Clustering analysis and genome inference of pisang raja local cultivars (Musa spp.) from Java Island by Random Amplified Polymorphic DNA (RAPD) Marker. J Trop Biodiv Biotechnol 4 (2): 42-53.

Reni R 2015 Analisis Keragaman Genetik Genotipe Elit Jagung (Zea mays L.) Tahan Bulai Berbasis Marka Simple Sequence Repeats (SSRs) [thesis]. Program Studi Agroteknologi Jurusan Budidaya Pertanian Fakultas Pertanian Universitas Hasanuddin, Makasar. [Indonesian]
Rimbawanto A, Widyatmoko W, Sulistyowati P. 2006. Distribusi keragman genetik populasi Santalum album berdasarkan penanda RAPD. Jurnal Pemuliaan Tanaman Hutan 3: 175-181. [Indonesian]

Roldàn-Ruiz I, Dendauw J, Van BE, Depicker A, de Loose M. 2000. AFLP markers reveal high polymorphic rates in ryegrasses (Lolium spp.). Mol Breeding 6 (2): 125-134.

Sambrook J, Russel DW. 2001. Molecular Cloning (A Laboratory Manual), Volume 1, 3rd ed. Cold Spring Harbor Laboratory, New York.

Subagio H, Aqil M 2013 Pengembangan Produksi Sorgum di Indonesia. Seminar Nasional Inovasi Teknologi Pertanian. BPTP Kalimantan Selatan, Kalimantan Selatan. [Indonesian]

Sundari, Arumingtyas EL, Hakim L, Azrianingsih R, Wahyudi D. 2017. Genetic variability of local durian (Durio zibethinus Murr.) in Ternate Island based on RAPD markers. Plant Cell Biotechnol Mol Biol 18 (1): 68-75.

Sundari, Mas'ud A, Arumingtyas EL, Hakim L, Azrianingsih R, Wahyudi D. 2019. Taxonomical Status of Local Durian (Durio spp.) from Ternate Island North Maluku base on morphological character and geographical factor. Intl J Conserv Sci 10 (4): 711-720.

Tingey SV, Rafalski JA, Hanafey MK. 1994. Genetic analysis with RAPD markers," in Plant Molecular Biology. Springer, Berlin.

Uslan, Pharmawati M. 2015 Optimasi konsentrasi DNA dan $\mathrm{MgCl} 2$ pada reaksi Polymerase Chain Reaction-Random Amplified Polymorphic DNA untuk analisis keragaman genetik tanaman faloak (Sterculia quadrifida $\mathrm{R} . \mathrm{Br}$ ) (Optimization of DNA and $\mathrm{MgCl} 2$ Concentrations in Polymerase Chain Reaction. Bios Logos 5 (1): 26-34. [Indonesian]

Weising K, Nybom H, Pfenninger M, Wolff K, Kahl G. 2005. Principles, Methods, and Applications DNA Fingerprinting," in Plants. CRC Press, Boca Raton.

Wijayanto T, Dirvamena B, Ente L. 2013. Hubungan kekerabatan aksesi Pisang Kepok (Musa paradisiaca forma typica) di Kabupaten Muna berdasarkan karakter morfologi dan penanda RAPD. Jurnal Agroteknos 3 (3):163-166. [Indonesian]

Yusuf Y, Pohan A, Syamsuddin S. 2013. Jagung makanan pokok untuk mendukung ketahanan pangan di Provinsi East Nusa Tenggara. Prosiding Seminar Nasional Serealia. Balai Penelitian Tanaman Serealia, Maros, 2013. [Indonesian]

Yulita KS, Naiola N. 2013. Keragaman genetik beberapa aksesi jagung dari East Nusa Tenggara berdasarkan profil Inter Simplet Sequence Repeat (ISSR). Jurnal Biologi Indonesia 9 (2): 255-264. [Indonesian]

Zulfahmi R. 2013. Genetic diversity of Eurycoma longifolia Jack based on Random Amplified Polymorphic DNA marker. J Trop For Manag 3 (2): 41-52. 